\title{
OPEN Stable isotopes and predation marks shed new light on ammonoid habitat depth preferences
}

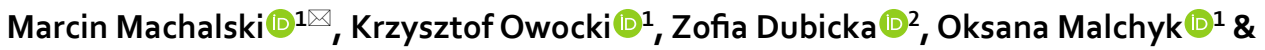 \\ Weronika Wierny ${ }^{2,3}$
}

Ammonoids are extinct cephalopods with external shells which predominated in many late Paleozoic and Mesozoic marine ecosystems. Stable isotope data from ammonoid shells constitute primary tools for understanding their palaeohabitats. However, in most sedimentary successions globally the aragonitic shells of ammonoids are dissolved during fossilisation process and therefore not available for geochemical studies. We overcome this taphonomic bias by analysing the better preservable calcitic elements of the ammonoid jaws (aptychi). We study moulds and aptychi of two successive members, temporal subspecies in our interpretation, of a scaphitid evolutionary lineage from a Late Cretaceous chalk succession in Poland. In order to reconstruct their habitat depth preferences, we apply the powerful combination of stable isotope data from aptychi and co-occurring benthic and planktic foraminifera with an analysis of predation marks preserved on scaphitid specimens. On this basis we conclude that the populations of the older subspecies led a nektic, and those of the younger subspecies, a nektobenthic lifestyle. The shift in habitat depth preferences took place probably as a response of local populations to the shallowing of the sea. Previous studies largely assumed stable depth preferences for ammonoid species, genera and even higher clades. Our study casts doubts over such generalizations by pointing out that ammonoids could have been more flexible in their depthrelated behaviour than anticipated.

Ammonoids rank amongst the most diverse, abundant and best studied clades in the history of life ${ }^{1-3}$. These extinct cephalopods with external chambered shells predominated in many late Paleozoic and Mesozoic marine ecosystems. They followed a pelagic mode of life ${ }^{4}$, inhabiting the water column either close to the sea floor as nektobenthos, or higher up as nekton or plankton. Ammonoid depth preferences may be reconstructed based on several methods, including comparative morphology of conchs, mechanical properties of shell material, and facies inferences ${ }^{4-8}$. The use of stable isotope thermometry of aragonitic ammonoid shells has yielded particularly promising results for depth inferences ${ }^{9-12}$. However, this method excludes from study those specimens that originate from carbonates in which the aragonitic shells were dissolved during fossilisation proces, leaving only natural moulds (steinkerns). This is just the case in the white chalk facies, which predominated in the Boreal Chalk Sea of Europe during the Late Cretaceous ${ }^{13-15}$.

Absence of original shells does not mean, however, that the European chalk ammonoid faunas ${ }^{16,17}$ are completely out of reach where isotope palaeothermometry is concerned. The chalk locally yields aptychi, that is paired calcitic coverings of the lower ammonoid jaws ${ }^{18,19}$. According to Kruta et al. ${ }^{20}$, aptychi were secreted in equilibrium with ambient sea water and are thus potential archives of palaeobiologically meaningful isotope data.

Following the pionieering study by Kruta et al. ${ }^{20}$, we use stable isotope thermometry of aptychi for the reconstruction of habitat depth preferences of a scaphitid, that is member of the ammonoid family Scaphitidae, from the European Boreal Chalk Sea. We target Hoploscaphites constrictus (Fig. 1), a species common in the Maastrichtian of Europe ${ }^{21,22}$. More specifically, we study two successive members (which we interpret as two temporal subspecies, or chronosubspecies) of the Hoploscaphites constrictus evolutionary lineage ${ }^{21}$, based on specimens and samples from three intervals in the shallowing-upwards epicontinental chalk succession of late Maastrichtian age exposed at Chełm, Poland ${ }^{23,24}$. In order to reconstruct the preferred position of these ammonoids in the water column, we compare temperatures calculated from the oxygen isotope compositions of aptychi with those of cooccurring foraminifera with known bathymetric preferences; we also study carbon isotopes for additional clues ${ }^{11}$.

${ }^{1}$ Institute of Paleobiology, Polish Academy of Sciences, Twarda 51/55, 00-818 Warsaw, Poland. ${ }^{2}$ Faculty of Geology, University of Warsaw, Al. Żwirki i Wigury 93, 02-089 Warsaw, Poland. ${ }^{3}$ Polish Geological Institute-National Research Institute, Rakowiecka 4, 00-975 Warsaw, Poland. ${ }^{\circledR}$ email: mach@twarda.pan.pl 

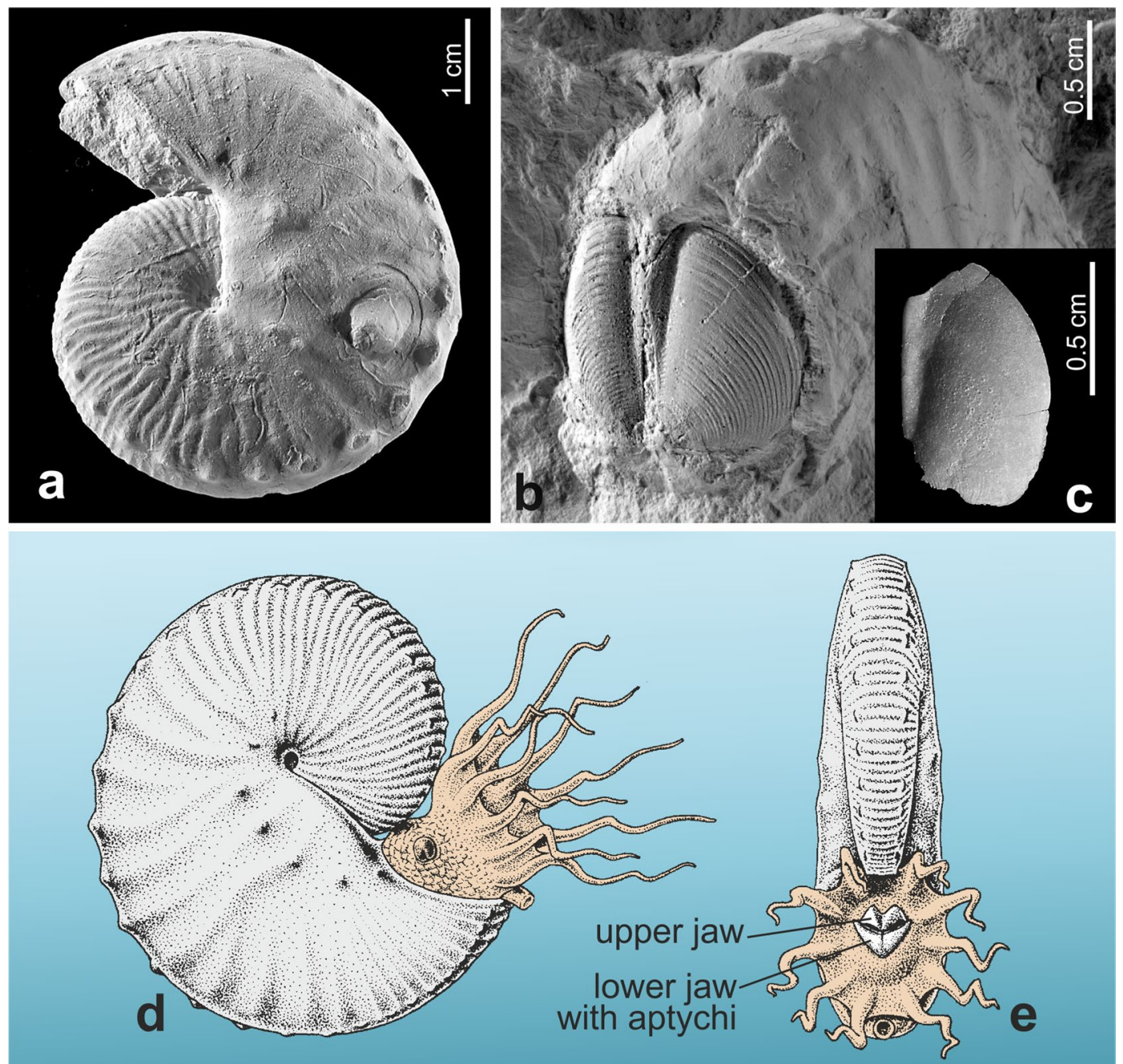

Figure 1. The scaphitid ammonoid studied. (a) Mould of Hoploscaphites constrictus lvivensis in lateral view (holotype of the subspecies, ZPAL Am. 12/1051). (b) A pair of aptychi in internal mould preservation (with discernible growth increments present on the dorsal surfaces of the original aptychi) inside a mould of $H$. $c$. lvivensis, ZPAL Am. 12/796 (see Machalski, 2021 22 for interpretation of this specimen and for terminology of aptychi). (c) Single aptychus, ZPAL Am. 24/104, in ventral view. (d, e). Speculative life restoration of the animal in lateral $(\mathbf{d})$, and anterior $(\mathbf{e})$, views. Specimens $(\mathbf{a}-\mathbf{c})$ from Chełm.

As an independent test of palaeothermometric inferences, we study predation marks preserved on the scaphitid moulds from Chełm ${ }^{25}$. Quantitative proportions between the various types of such marks in fossil assemblages provide insights into the depth preferences of the ammonoid prey ${ }^{26,27}$.

Habitat depth preferences are an important issue in the discussions on the ammonoid palaeobiology $4,5,8,10,28$. Our results shed a new light on this issue by documenting a shift in depth preferences which took place between closely related members (successive chronosubspecies) of a single lineage of these cephalopods.

\section{Geological setting}

Detailed data on geological setting are provided in the Supplementary Information (SI). Briefly, our specimens and samples come from the 40-m-thick chalk succession exposed at the cement-plant quarry of Chełm, Poland ${ }^{23}$ (Fig. 2; SI-Figs. 1, 2). Due to peculiarities of chalk excavation in the mine (see SI), our sampling of macrofossils, including scaphitid moulds and aptychi, was restricted to three chalk intervals, A-C, each 2 m thick (Fig. 2, SI-Fig. 1).

During the Late Cretaceous, the present-day site of Chełm was located in the eastern part of the the Boreal Chalk Sea of Europe (Surlyk et al. ${ }^{13}$; Thibault et al. ${ }^{14}$; Wilmsen and Niebuhr ${ }^{15}$ ). The Chełm chalk was laid down in an epicontinental (epiplatform) setting and was separated from the classical areas of chalk sedimentation in Denmark and northern Germany by an area in which sedimentation of spiculitic limestones, the so-called opokas, prevailed (e.g., Leszczyński ${ }^{29}$; Jurkowska and Swierczewska-Gładysz ${ }^{30}$ ). The current coordinates of the Chełm locality are $51.1303^{\circ} \mathrm{N}, 23.5303^{\circ} \mathrm{E}$. According to GPlates Web Service ${ }^{31}$, the palaeo-position of this site 


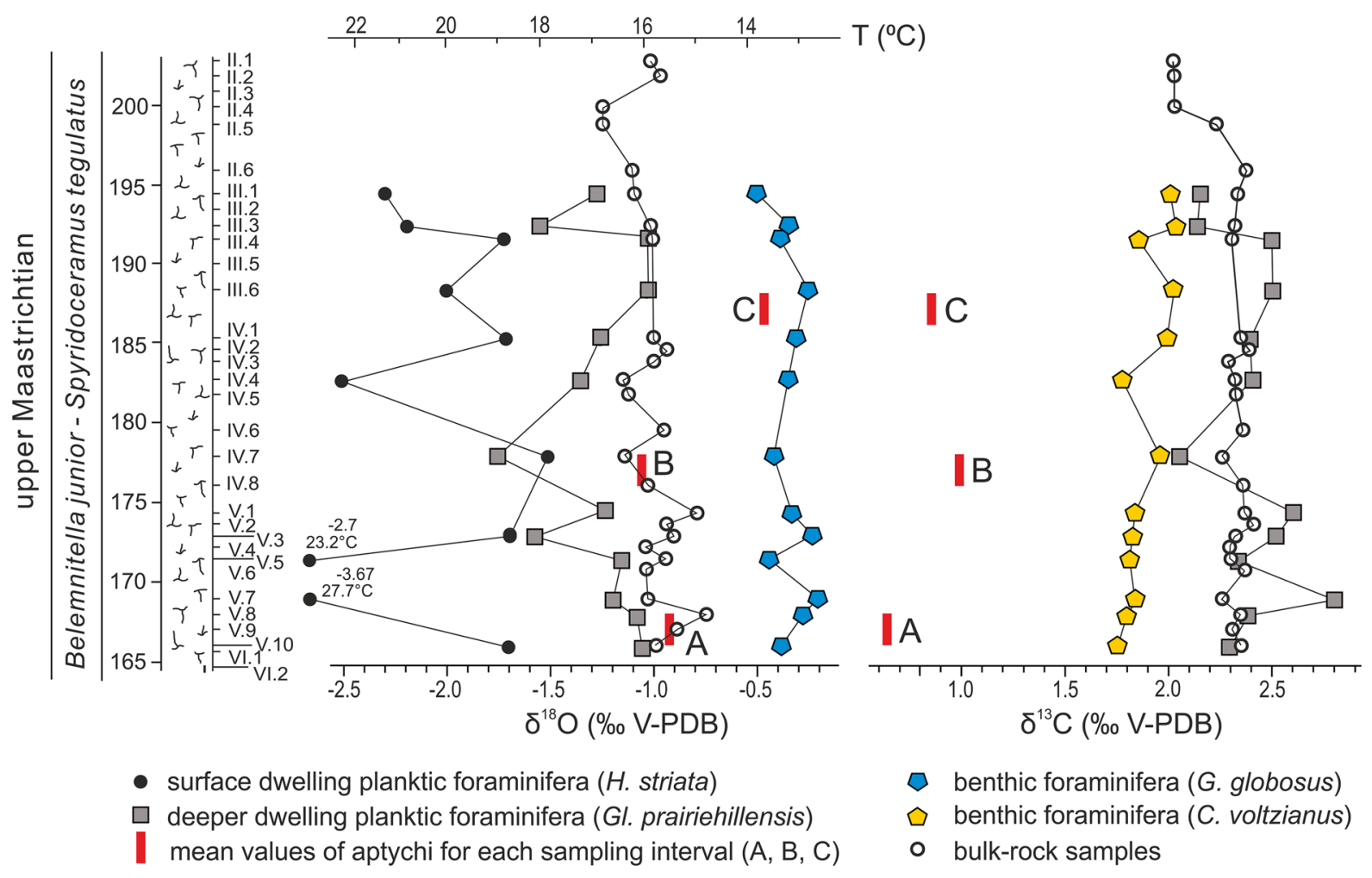

Figure 2. The chalk section at Chełm, with quarry levels VI-II, sampling intervals A-C, and stratigraphic variations in $\delta^{18} \mathrm{O}$ and $\delta^{13} \mathrm{C}$ values of benthic and planktic foraminifera and bulk-rock samples. Red bars are mean $\delta^{13} \mathrm{C}$ and $\delta^{18} \mathrm{O}$ values of aptychi of Hoploscaphites constrictus from intervals A-C. H., Heterohelix; Gl., Globigerinelloides; G., Gyroidinoides; C., Cibicidoides.

69 myr ago was $47.77^{\circ} \mathrm{N}, 22.16^{\circ}$ E. During the Maastrichtian, this area witnessed a progressive cooling trend with lower and higher temperature fluctuations ${ }^{14}$.

The Chełm chalk is assigned to the lower upper Maastrichtian Belemnitella junior and Belemnitella juniorSpyridoceramus tegulatus zones of the standard European Boreal subdivisions ${ }^{21,23,32}$. Based on correlation with the Stevns-1 reference core in Denmark (SI-Fig. 2; Surlyk et al. ${ }^{33}$; Thibault et al. ${ }^{14}$ ), we approximately date intervals A, B, and C as 69.0,68.7, and 68.3 Ma, respectively. The Chełm chalk matches the characteristics of the 'benthos-poor chalk' in the Boreal Chalk Sea facies model ${ }^{13}$. Planktic foraminiferal assemblages point to sea level fall during chalk deposition, from a depth of c. $100 \mathrm{~m}$ for interval $\mathrm{A}$, to that of several dozen metres for interval $\mathrm{C}$ (see Dubicka and Peryt ${ }^{23,24}$, also SI). The shallowing upwards trend for the Chełm succession is confirmed by REE data (SI). Benthic foraminifera assemblages ${ }^{23}$, and macro- and trace-fossils (SI) testify to oxic bottom conditions and normal water salinity during deposition of the chalk. We also failed to find pyrite framboids in the sediment which would potentially indicate temporal dysoxia during deposition of the chalk (see SI, compare Tagliavento et al. $^{34}$ ).

\section{Material assessment}

The material studied has been identified and assessed along several lines of evidence in terms of its suitability to the present study (see SI, and SI-Figs. 3-11); a brief summary follows below.

The studied scaphitids represent the late Maastrichtian part of the Hoploscaphites constrictus evolutionary lineage (SI-Fig. 3). In terms of the subdivison of this lineage into temporal subspecies based on materials from several regions of Europe (SI-Figs. 3-4; $\mathrm{Machalski}^{21}$ ), the scaphitid moulds and co-occurring aptychi (Fig. 1a-c) from intervals $\mathrm{A}$ and $\mathrm{B}$ at Chełm are assigned to $H$. c. lvivensis, and those from $\mathrm{C}$ to $H$. $c$. aff. crassus, intermediate in shell ornament to $H$. c. crassus (SI-Figs. 5-7). The latter subspecies was interpreted by Machalski ${ }^{21}$ as a direct descendant of H. c. lvivensis; the presence of the transitional form at Chełm provides an additional argument for this interpretation.

Post-mortem transport of the scaphitid remains from distant habitats is ruled out on taphonomic grounds. Specifically, the in situ character of the assemblages studied is indicated by occurrences of aptychi in scaphitid body chambers (SI-Fig. 7), the common presence of double-valved aptychi (SI-Fig. 6), as well as the occurrence of carbonised remnants of the originally chitinous lower jaws still attached to aptychi (SI-Fig. 6).

The pristine preservation documented on microstructural and geochemical grounds for aptychi (SIFigs. 9-10) and foraminifer ${ }^{35}$ make them suitable for palaeobiologically oriented geochemical analyses. Firstly, the lack of diagenetic alteration of the aptychi is indicated by the presence of well-defined increments and growth lines (SI-Fig. 9) and pristine lamellar microstructures with distinct tablets without any signs of diagenetic 


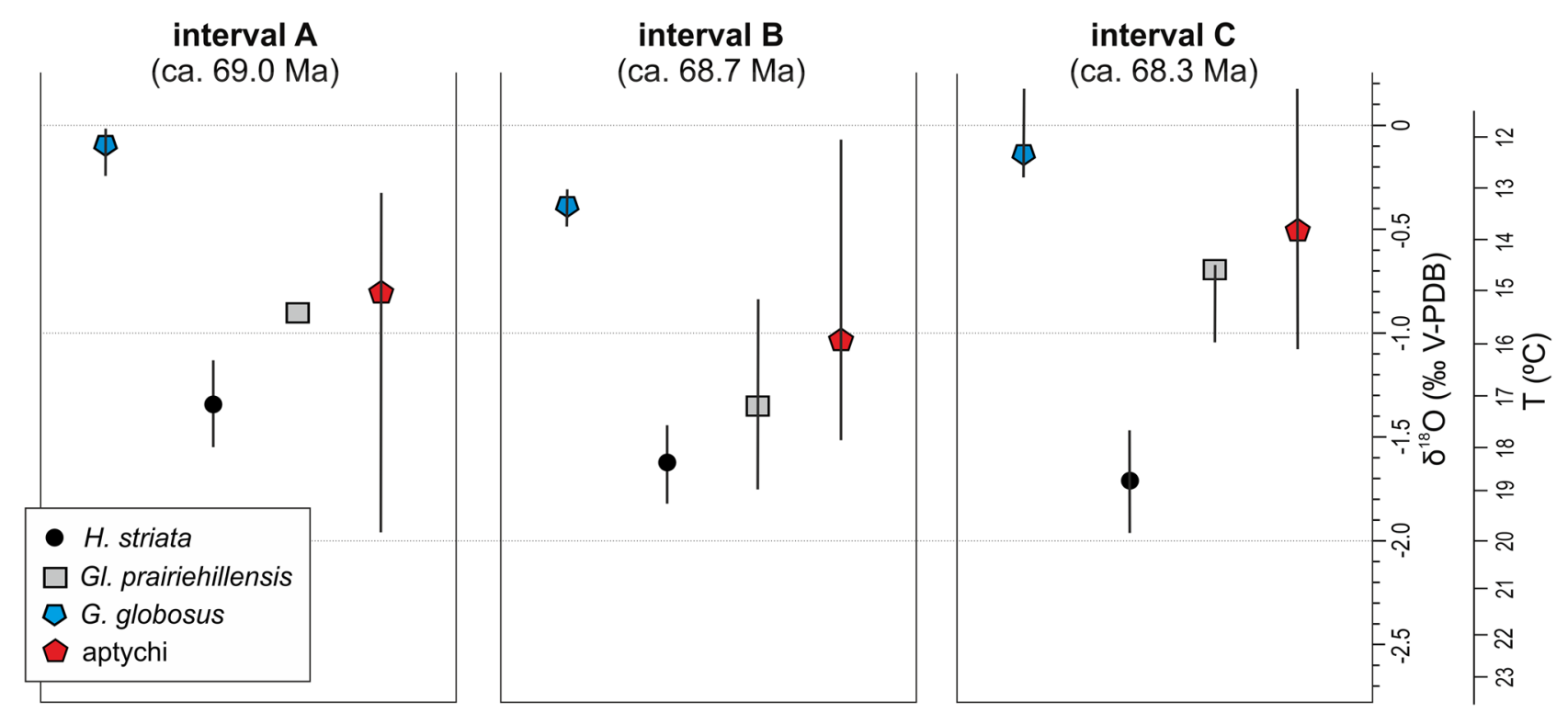

Figure 3. Box and whisker plots of $\delta^{18} \mathrm{O}$ data for targeted foraminifera and aptychi of Hoploscaphites constrictus from intervals $\mathrm{A}-\mathrm{C}$ at Chełm, grouped by taxon. Each box represents the mean value and whiskers are extended between the maximum and minimum $\delta^{18} \mathrm{O}$ values. H., Heterohelix; Gl., Globigerinelloides; G., Gyroidinoides.

secondary phases (SI-Fig. 9). This means a high Preservation Index 5 (excellent preservation) of the aptychi studied $^{20}$. Secondly, most of the aptychi examined by us with Cathodoluminescence (CL) microscopy show no luminescence (SI-Fig. 10), indicating the absence of diagenetic alteration. Thirdly, the results of Electron Microprobe Analyses (EMPA) suggest trace element Mn, Sr, Ba content to be below the detection limit of the microprobe (SI Table 2), which is characteristic for diagenetically unaltered samples. Fourthly, the ontogenetic stable isotope profiles of aptychi from intervals A-C commonly reveal oscillating values of $\delta^{18} \mathrm{O}$ and $\delta^{13} \mathrm{C}$ (SI-Figs. 15-16) which may be interpreted as reflecting original seasonal biological cycles; diagenesis tends to homogenise such signals.

Among foraminifera selected for analyses (SI-Fig. 11), there are two benthic species, Gyroidinoides globosus and Cibicidoides voltzianus, and two planktic ones, surface-dwelling Heterohelix striata and deeper-dwelling Globigerinelloides prairiehillensis. Of these, G. globosus, H. striata and G. prairiehillensis precipitated oxygen, and $C$. voltzianus and $G$. prairiehillensis carbon isotopes in near-equilibrium with ambient water ${ }^{35}$. Thus, these foraminifera are expected to yield reliable data for reconstructing the depth-related temperature profile of the water column, against which the scaphitids may be positioned via isotope data from aptychi.

\section{Results}

Stable isotope analyses. Our isotope analyses are based on bulk rock and foraminiferal samples from the entire section and bulk and serially sampled aptychi from intervals A-C. We used isolated, i.e. found loose in the chalk, aptychi for these analyses. The oxygen $\left(\delta^{18} \mathrm{O}\right)$ and carbon $\left(\delta^{13} \mathrm{C}\right)$ isotope analyses of the calcite and calculated palaeotemperatures for the entire section are presented in Fig. 2, and for intervals A-C in Figs. 3, 4a,b and 5, and SI-Figs. 12-16 (see SI Tables 3-13 for rough data).

In order to identify significant differences in $\delta^{18} \mathrm{O}$ and $\delta^{13} \mathrm{C}$ isotope values between intervals $\mathrm{A}-\mathrm{C}$, we perform the non-parametric Kruskal-Wallis test (for each foraminiferal species separately and the bulk-sampled aptychi). Only $\delta^{18} \mathrm{O}$ isotope signatures for aptychi are significantly different (Kruskal-Wallis test, Hc=14.73, $p=0.0006$ ) with heavier oxygen signatures in specimens from interval C (Mann-Whitney pairwise comparisons). Changes in values of $\delta^{13} \mathrm{C}$ show a negligible variance for aptychi and C. voltzianus (Kruskal-Wallis test, Hc $=4.989$, $p=0.0827 ; \mathrm{Hc}=6.433, p=0.0404$, respectively) with the former having slightly lighter $\delta^{13} \mathrm{C}$ for interval A and the latter having heavier $\delta^{13} \mathrm{C}$ for interval $\mathrm{C}$. We also test the oxygen isotope variation through ontogeny in some aptychi from intervals A-C (Fig. 5; SI-Figs. 15-16) and find no significant differences between these intervals.

Predation marks. Two types of lethal injuries inflicted by durophagous predators are discernible on the moulds of Hoploscaphites constrictus from Chełm (SI-Fig. 8; see also Machalski and Malchyk ${ }^{25}$ ). The ventral injuries are represented by subcrescentic or $\mathrm{V}$-shaped notches on the ventrolateral sector of the shell, predominantly near the base of the body chamber. The lateral injuries are represented by subcircular to irregular holes on the flanks of the body chamber. The frequency of these two types of predation marks fluctuates between the sampled intervals, with a marked increase in abundance of lateral traces in interval C (Fig. 4c). The ratio of lateral to ventral traces in the sampled intervals equals 1.16 for interval A, 1.39 for B, and rises to 8.25 in C (SI Table 1). There is no clear relationship between types of predation marks and their frequency on ammonoid shells in the sampled intervals (Kruskal-Wallis test, $\mathrm{Hc}=1.143, p=0.56$ ). 
interval A

(ca. 69.0 Ma) interval B

(ca. 68.7 Ma) interval C

(ca. 68.3 Ma)
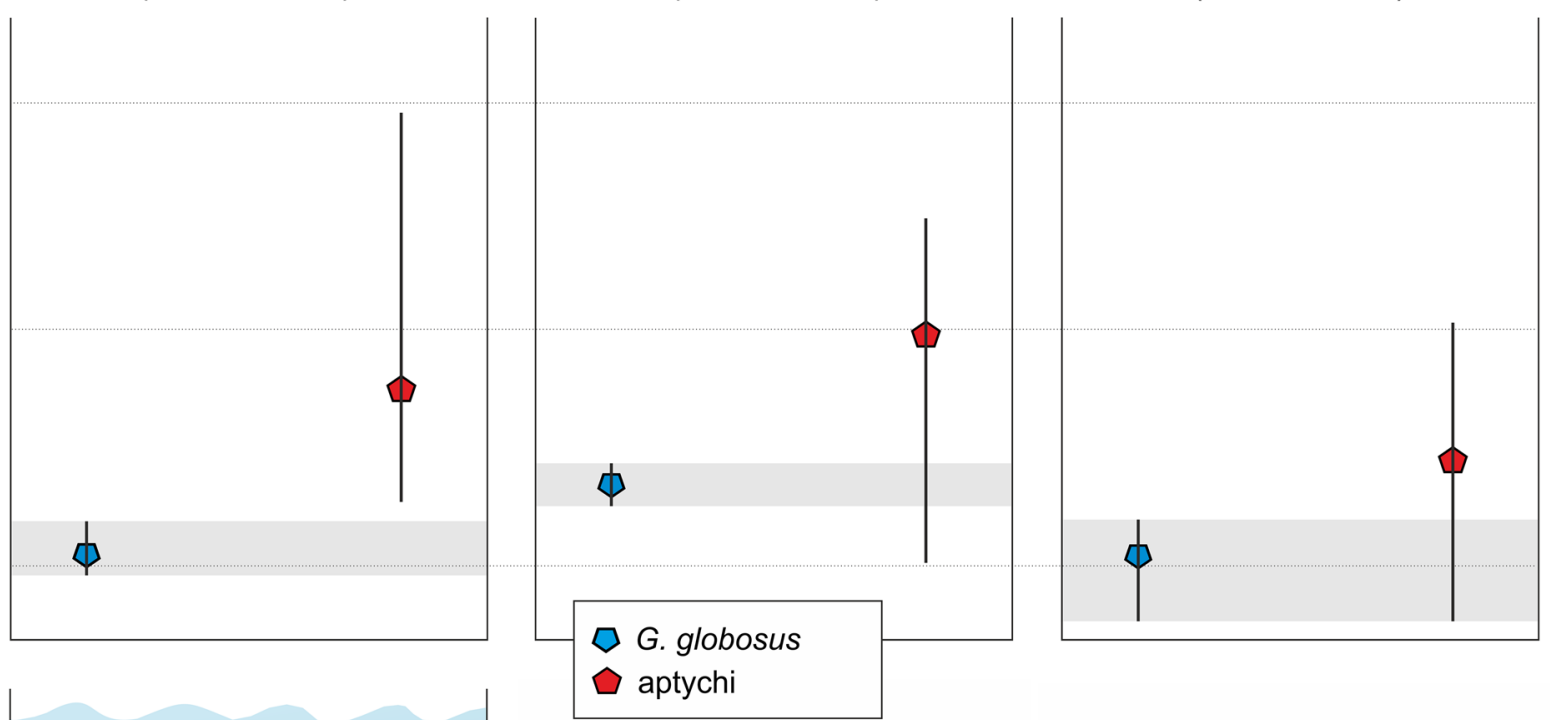

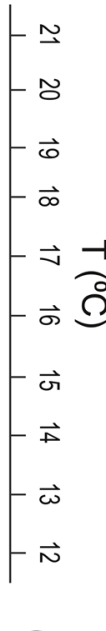

a

H. striata

$17.2 \mathrm{C}$

\section{Gl. prairiehillensis}

$15,3^{\circ} \mathrm{C}$

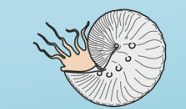

H. c. Ivivensis $15,0^{\circ} \mathrm{C}$

(-7) $12,2^{\circ} \mathrm{C}$

G. globosus
H. striata

18.4 C

Gl. prairiehillensis

$17,2^{\circ} \mathrm{C}$
(A) $13,3^{\circ} \mathrm{C}$

G. globosus
H. c. Ivivensis $16,0^{\circ} \mathrm{C}$

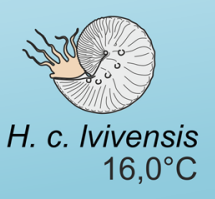

$18,8 \mathrm{C}$

GI. prairiehillensis

14, $6^{\circ} \mathrm{C}$

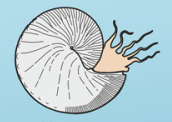

H. c. aff. crassus

$13,8^{\circ} \mathrm{C}$

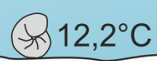

G. globosus
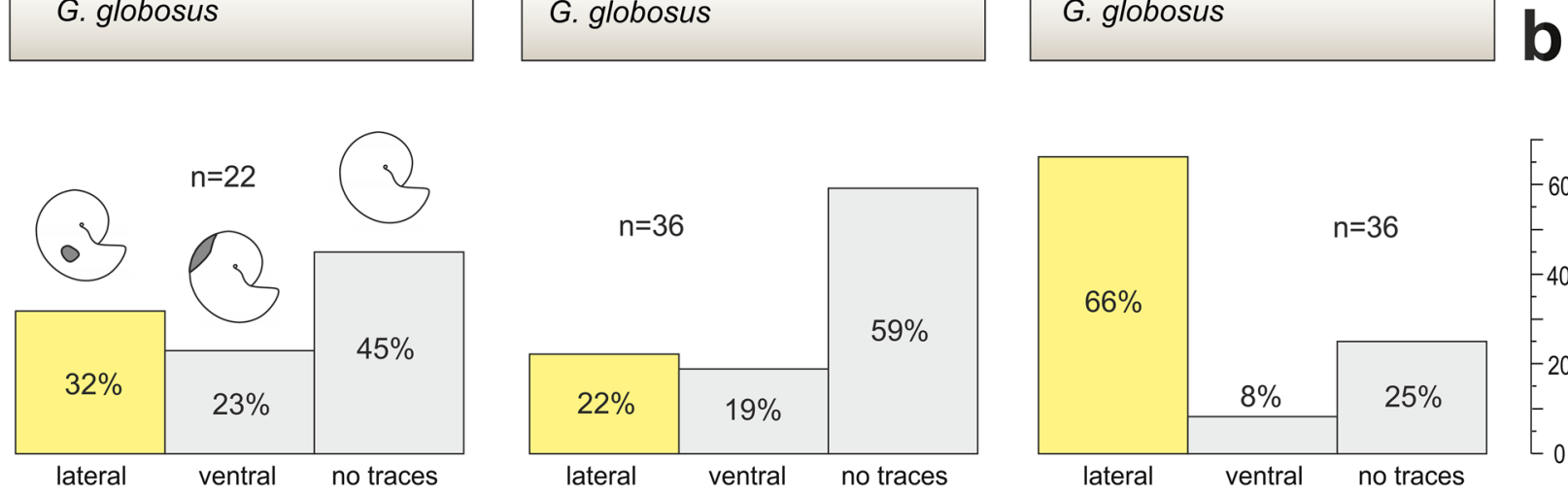

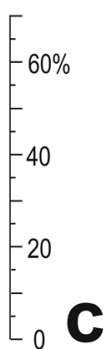

Figure 4. A combination of stable isotope and palaeotemperature data from aptychi of Hoploscaphites constrictus and foraminifera with data on the predation marks preserved on moulds of $H$. constrictus, intervals A-C, Chełm section. (a) Box and whisker plots of temperature gradient traversed by the scaphitids studied (based on $\delta^{18} \mathrm{O}$ data from aptychi). Each box represents the mean value and whiskers are extended between the maximum and minimum temperature values. Grey shaded areas represent putative bottom waters gradient based on $\delta^{18} \mathrm{O}$ data from the benthic foraminifer G. globosus. (b) Positions of taxa studied in the water column of the shallowing Maastrichtian sea, based on mean palaeotemperatures from $\delta^{18} \mathrm{O}$ data. (c) Incidence of predation traces on H. constrictus (see SI-Fig. 8). H., Heterohelix; Gl., Globigerinelloides; G., Gyroidinoides; C., Cibicidoides; H. c., Hoploscaphites constrictus. 


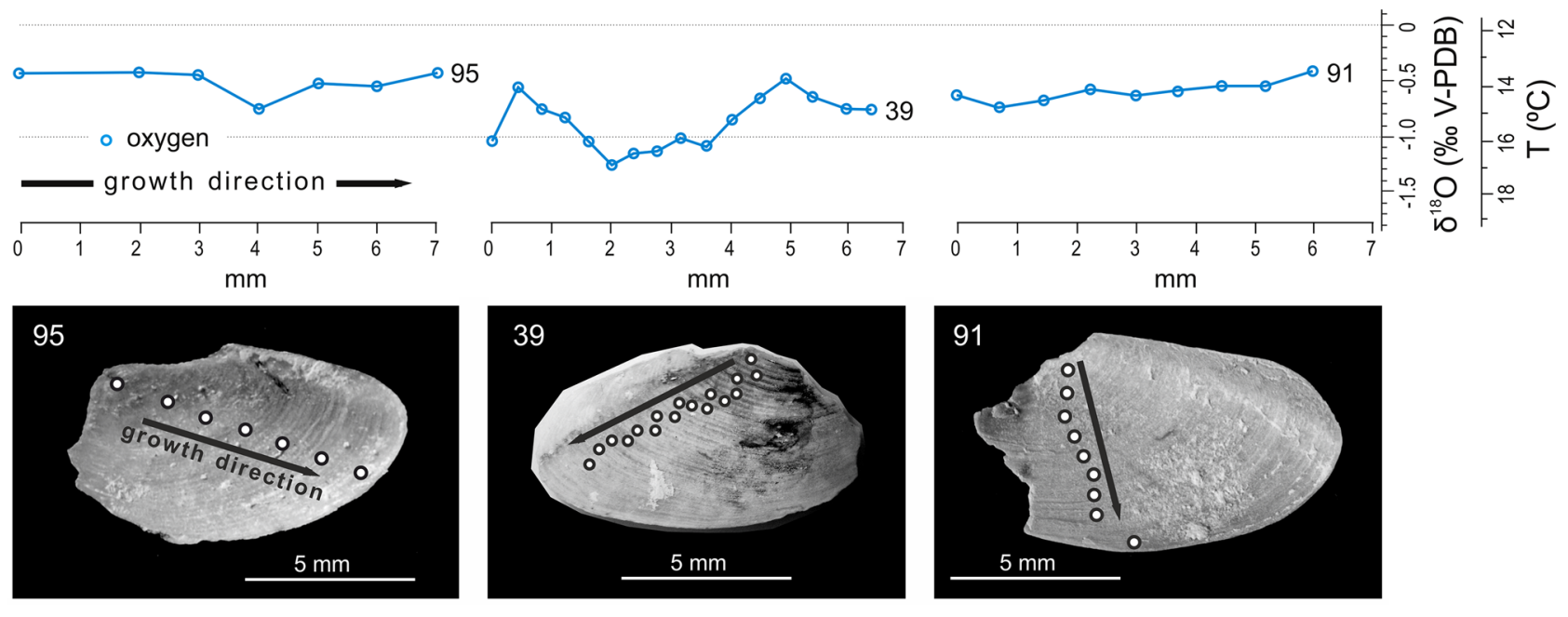

Figure 5. Examples of ontogenetic $\delta^{18} \mathrm{O}$ variation in aptychi of Hoploscaphites constrictus (from left to right: ZPAL Am. 24/95 from interval A, 39 from interval B, and 91 from interval C), photographed from their concave, anatomically dorsal, side which reveals growth increments (compare Machalski, 2021 22 ); white circles denote sampling points.

\section{Discussion}

The occurrence of exclusively stenohaline micro- and macrofauna throughout the Chełm section (see Geological setting section above and SI) allows us to exclude salinity changes as a factor controlling our oxygen stable isotope results; therefore we interpret these results in terms of palaeotemperatures.

The positions of Heterohelix striata, Globigerinelloides prairiehillensis and Gyroidinoides globosus in the water column reconstructed here on the basis of the oxygen-derived temperatures (Fig. 4a,b) are consistent with the inferred habitat depths of these foraminifera ${ }^{24,35}$ The thermal gradient between the surface and bottom of the water column may be estimated at $4-5{ }^{\circ} \mathrm{C}$, based on the temperature differences between the surface $H$. striata and benthic G. globosus. In all intervals studied, palaeotemperatures calculated from the aptychi locate Hoploscaphites constrictus in a position between the deeper-dwelling planktic $G$. prairiehillensis and the benthic $G$. globosus, closely approximating the latter in interval C (Fig. 4a,b). Statistical testing indicates a significant shift for scaphitid aptychi towards heavier oxygen values in C, suggesting a change of habitat into cooler, deeper waters, closer to the bottom than in A and B. No significant changes in thermal gradient between the samples from intervals A-C are recorded. There is a non-significant shift of dissolved inorganic carbon towards heavier $\delta^{13} \mathrm{C}$ values in the aptychi from interval $\mathrm{C}$, which we link to the shallowing of the sea (the $\delta^{13} \mathrm{C}_{\mathrm{DIC}}$ values tend to increase upwards the water column and towards the shore ${ }^{11}$ ).

It is important to note that the isotope results from bulk-sampled aptychi are averages which reflect the net sum of movements of particular individuals throughout the water-column during the sampled periods. Therefore, these results indicate the most commonly adopted (preferred) positions of these animals within the watercolumn. The lack of significant directional trends in the $\delta^{18} \mathrm{O}$ (and $\delta^{13} \mathrm{C}$ ) isotope values among serially sampled aptychi suggests that the habitat depth of their owners did not significantly change since the later juvenile stages (no records of the earlier stages are available due to damage of the apical portions of all analysed specimens, Figs. 1c, and 5 and SI-Figs. 6 and 9).

In summary, the palaeotemperatures gained from aptychi (Figs. 3 and 4a,b) suggest that H. c. lvivensis from intervals A and B shared the same ecozone with the deeper-water planktic foraminifer G. prairiehillensis, while H. c. aff. crassus from interval C was very close in its habitat to the benthic G. globosus. On this basis, a predominantly nektic mode of life may be inferred for H. c. lvivensis and a nektobenthic (demersal) one for $H$. c. aff. crassus (Fig. 6). This habitat shift must have occurred sometime between deposition of intervals B and C, i.e., between 68.7, and 68.3 Ma. These inferences can be verified by data on predation marks. Following Klompmaker et al. $^{36}$, we interpret the ventral damages as inflicted by predatory fish or coleoid cephalopods. These animals could follow either nektic or nektobenthic life, and therefore their traces are equivocal for bathymetry. The lateral marks were interpreted by Machalski and Malchyk ${ }^{25}$ as left by predatory swimming crabs, following Fraaye $\mathrm{e}^{37}$. Here, we prefer another interpretation - that the lateral injuries result from predatory activity of stomatopods, which smashed ammonoid shells with their raptorial appendages ${ }^{26}$ (see SI for discussion). These crustaceans are exclusively benthic animals ${ }^{26,38}$. Therefore, the major increase in abundance of their traces on $H$. $c$. aff. crassus moulds from interval C (Fig. 4c, SI Table 1) confirms the demersal mode of life inferred for this subspecies from isotope thermometry (Fig. 6).

The depth preferences of Nautilus, the only Recent analogue of extinct ectocochleate cephalopods, vary between populations, and are controlled by a variety of factors, including feeding preferences, temperature, and requirements for buoyancy regulation ${ }^{39}$. Nautilus is an active scavanger moving several hundred meters up and down along reef slopes, and its maximum depth range (over $700 \mathrm{~m}$ ) is related to shell strength preventing it from implosion under water pressure ${ }^{40}$. In contrast, scaphitids are thought to have been rather sluggish, mostly 


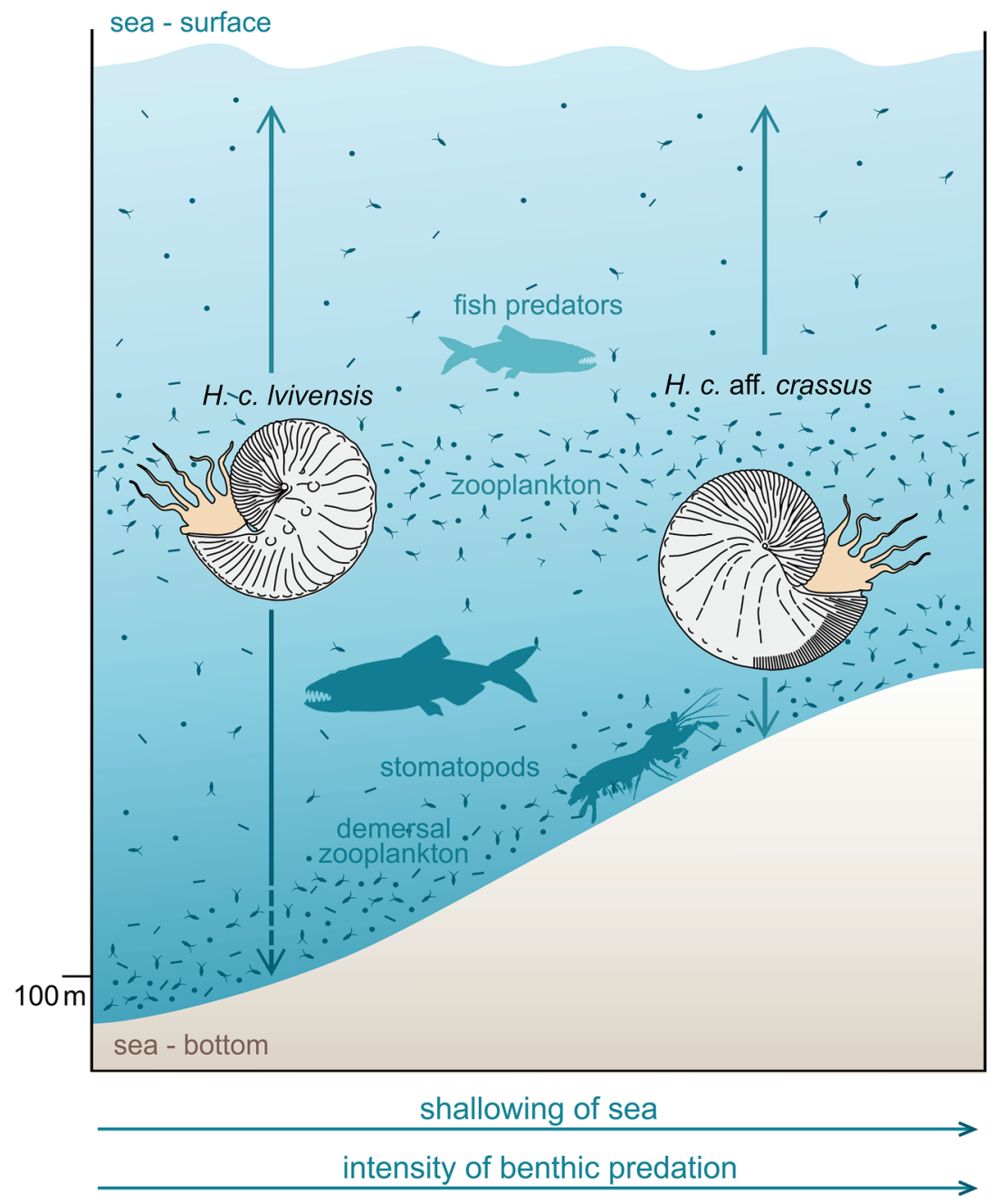

Figure 6. The inferred shift in habitat depth preferences of Hoploscaphites constrictus along with shallowing of the sea at the Chełm site. See text for further explanations.

demersal swimmers or occassional passive floaters, feeding on zooplankton and confined to shallow-marine milieus by virtue of their thin shells ${ }^{41,42}$. More specifically, Tsujita and Westermann ${ }^{43}$ calculated maximum habitat depths for Campanian and Maastrichtian scaphitids from Canada based on septal strength, suggesting that most of these species could not venture below depths of $100 \mathrm{~m}$. For their Hoploscaphites sp. a, which is most closely similar in shape and size to H. constrictus, these authors estimated a maximum habitat depth of c. $70 \mathrm{~m}$. By analogy, we posit broadly similar depth restrictions for European scaphitids. According to our estimations, basin depth at Chełm ranged from $100 \mathrm{~m}$ for interval A to several dozens of metres for C (see SI for discussion). We therefore propose that during deposition of the chalk intervals A and B (69.0, and 68.7 Ma), the sea floor was located near the maximum habitat depth of Hoploscaphites constrictus (Fig. 6). The majority of individuals spent most of their time high in the water column, living within and feeding on zooplankton 'clouds' ${ }^{44}$. That some individuals occasionally descended to the bottom is evidenced by traces of stomatopod predation on $H$. $c$. lvivensis from intervals $\mathrm{A}$ and $\mathrm{B}$. The situation was different during deposition of the shallowest chalk interval $\mathrm{C}$ $(68.3 \mathrm{Ma})$. At this time, $H$. constrictus aff. crassus populations followed a demersal life style, conducting massive exploration of the sea floor. They presumably fed here mainly on demersal zooplankton, that is mobile, benthic organisms, which periodically move up into the water column ${ }^{45}$. At the same time, the scaphitids more often fell prey to benthic stomatopods operating on the sea floor (Fig. 6).

The inferred change in lifestyle was associated with the replacement of Hoploscaphites constrictus lvivensis by another member of the evolutionary lineage, identified as H. c. aff. crassus. Therefore, it is tempting to explain this shift in terms of evolutionary process. However, our preferred hypothesis is that it reflects just an opportunistic, reversible response of local populations to new demands of local environment. Based on the Walter's Law of Facies, we expect that each of our samples A-C had its counterparts in bathymetrically different zones in other parts of the chalk basin. We hypothesise that the scaphitid populations from these zones led different mode of life than their Chełm equivalents. Testing of this hypothesis is, however, not possible with the data at hand. The Chełm section is the only one in Europe which allows for adequate sampling of this segment of the H. constrictus evolutionary lineage. Outside the Chełm quarry, H. c. lvivensis was identified only in the environs of Lviv, 
western Ukraine ${ }^{21}$. However, the outcrops that yielded these materials do not exist today, and only inadequately localised mould specimens and a few aptychi are available in the museum collections, which are unsuitable for a study like the present one.

\section{Conclusion}

Stable isotope data from ammonoid shells constitute primary tools for understanding of their palaeohabitats (e.g., Moryia ${ }^{10}$ ). However, in most sedimentary successions globally the aragonitic shells of ammonoids are dissolved during fossilisation process and therefore not available for geochemical studies. Following Kruta et al. ${ }^{20}$, we overcome this taphonomic bias by analysing the better-preservable calcitic elements of the jaws (aptychi) of a Late Cretaceous scaphitid species, Hoploscaphites constrictus, from a white chalk succession deposited in the Boreal Chalk Sea of Europe.

In order to study the depth preferences of $H$. constrictus, we applied the unique and powerful combination of stable isotope data from aptychi and co-occurring foraminifera with well established depth preferences with an analysis of predation marks preserved on scaphitid specimens. On this basis we infer a change in habitat depth preferences between two successive temporal subspecies of the Hoploscaphites constrictus lineage. This change took place probably in response to the shallowing of the sea documented for the succession studied (Fig. 6).

Our results have implications for understanding of ammonoid palaeobiology. As pointed out by Moryia ${ }^{28}$, a fundamental knowledge about habitat depth of ammonoids is crucial for understanding of their palaeoecology and mechanisms of evolution and extinction. Many previous studies assumed, either explicitly or implicitly, stable habitat depth preferences for particular ammonoid species, genera and even higher clades (e.g., Westermann ${ }^{5}$ and Moriya ${ }^{28}$ ), although the latter author mentioned a single case of reversal of depth preferences in one lineage, namely the Perisphinctoidea. As far as the scaphitids are concerned, these cephalopods are generally regarded to have been demersal animals ${ }^{8,41}$. Our study casts doubts over such generalizations, suggesting that ammonoids could have been more flexible in their depth-related behaviour than previously anticipated. Future studies, preferrably based on densely-spaced and stratigraphically well-constrained samples, are encouraged to explore this important issue in more detail.

\section{Material and methods}

Material studied. In total, 187 moulds of Hoploscaphites, 130 aptychi and 34 bulk-rock samples, plus a number of other macrofossils from Chełm have been collected and analysed. The material was collected by sampling of the entire section, with working levels II-VI as reference horizons, and from detailed sampling of three chalk intervals A-C, each $2 \mathrm{~m}$ thick (Fig. 2). Due to the way in which the chalk is excavated here, only these intervals made it possible to collect macrofossil samples that were sufficient for the present study. The macrofossil material is housed at the Institute of Paleobiology, Polish Academy of Sciences (PAS), Warsaw (abbreviated ZPAL Am. 12 and 24). Microfossil samples are stored at the Faculty of Geology, University of Warsaw. Ammonoid specimens from Chełm described by Machalski ${ }^{21}$ have also been studied for comparison.

Preparation of macrofossils. Specimens were prepared, both in the field and laboratory, using standard mechanical methods: hammer, chisel, needles, and a vibrotool (Paleotools, ME-9100).

Processing of foraminiferal samples. For carbon and oxygen isotope analyses of foraminiferal tests 34 bulk samples of circa $0.2 \mathrm{~kg}$ weight were processed. The samples were mechanically disintegrated in tap water, cleaned in an ultrasonic bath and washed through a 125 micron mesh. This procedure was repeated until obtaining foraminiferal tests completely devoid of infill. From each sample residue, adult, large-sized foraminiferal specimens were hand picked to microcentrifugal tubes. Each taxon (selected for specific ecological preferences and very weak vital effect, see chapter Selection of foraminifera in Supplementary Information) was picked separately to obtain foraminiferal monospecific material of a weight in excess of $2 \mu \mathrm{g}$.

Processing of aptychi and bulk-rock samples. For bulk carbon and oxygen isotope analyses of aptychi, 43 specimens in total were selected (15 from interval A, 16 from B, and 12 from C; all are isolated specimens). These specimens were pulverized and homogenized in an agate mortar. Additionally, 10 aptychi were serially sampled in order to detect ontogenetic variation in their stable isotope content ( 2 specimens from A, 6 from B, and 2 from C; 87 measurements in total). Carbonate samples were extracted from spot locations on the aptychi surfaces along the growth axis. Additionally, chalk matrix directly adjacent to the serially sampled aptychi was analysed, based on 8 samples.

Microstructural observations of aptychi. Sections of aptychi were prepared and examined at the Institute of Paleobiology PAS. These sections were made perpendicular to the aptychus surface, approximately along the growth axis of the aptychus. Petrographic observations were done using a Nikon Eclipse 80i transmitted light microscope fitted with a DS-5Mc cooled camera head. Measurements were made using image analysis software (NIS Elements D software, https://www.microscope.healthcare.nikon.com/products/software/nis-elements) from digital micrographs (Nikon DSIFi2). Observations were conducted in transmitted light, which enabled quick assessment of each fossil's microstructural organization and the presence of diagenetic minerals. Selected thin sections were carbon coated and analysed using cathodoluminescence (CL) microscopy. CL analysis was conducted at the NanoFun laboratory (Institute of Paleobiology PAS), using an HC1-LM hot cathode microscope with the following parameters: electron energy $14 \mathrm{keV}$, beam current density $0.1 \mu \mathrm{Amm}^{-2}$. For SEM studies of aptychi, selected polished sections (byproduct of cutting thin sections) were etched for 8-15 $\mathrm{min}$ in $8 \%$ for- 
mic acid, rinsed with Milli-Q water, and air-dried. Next, the specimens were placed on stubs with double-sided adhesive tape and sputter-coated with a conductive carbon film. Analyses were conducted at the Institute of Paleobiology PAS, using a Philips XL20 scanning electron microscope. SEM imaging provided high-resolution support for transmitted light observations; for example, SEM studies made it possible to obtain more detailed information on the preservation of the microstructure of aptychi. This instrument was operated at an acceleration voltage of $25 \mathrm{kV}$, a beam current of $98-103 \mathrm{nA}$ and a spot diameter of $3.5 \mu \mathrm{m}$.

Elemental analyses of aptychi. Contents of major, minor and trace elements in aptychi were examined on uncovered thin sections previously documented in transmitted light and were made using a Cameca SX-100 electron microprobe at the Joint-Institute Analytical Complex for Minerals and Synthetic Substances (Faculty of Geology, University of Warsaw, Poland). In total, 43 measurements from four aptychi were made. The mineral compositions were determined in wavelength dispersive spectral (WDS) mode on the EMPA using an accelerating potential of $15 \mathrm{keV}$, a $20 \mathrm{nA}$ beam current, $1 \mu \mathrm{m}$ beam size, peak and background counting times of 20-30 s and standard ZAF (PAP) correction procedures. A combination of natural and synthetic standards was used for calibration. The peak counting times were $10 \mathrm{~s}$ for major elements and $20 \mathrm{~s}$ for minor elements. At these durations, the average detection limits were 423 ppm for Mg; 190 ppm for Si; 232 ppm for Ca; 155 ppm for Al; 495 ppm for Sr; 517 ppm for Ba; 229 ppm for P; 189 ppm for S; 625 ppm for Fe; 593 ppm for Mn.

Stable isotope analyses. The stable isotope composition of carbonates studied (bulk rock, foraminiferal and aptychi samples) was analysed at the Warsaw Isotope Laboratory for Dating and Environment Studies of the Polish Academy of Sciences. The samples were dissolved in $100 \%$ phosphoric acid at $70{ }^{\circ} \mathrm{C}$, using a Kiel IV online carbonate preparation device, connected to a ThermoFinnigan Delta Plus mass spectrometer. The quality of the analysis was controlled by NBS-19 international standard measurements. The $\delta^{13} \mathrm{C}$ and $\delta^{18} \mathrm{O}$ values are given relative to the V-PDB standard. Analytical reproducibility was verified on the basis of the repeatability of the NBS-19 results, with an observed deviation of $<0.03 \%$ for $\delta^{13} \mathrm{C}$ and $<0.07 \%$ or for $\delta^{18} \mathrm{O}$ measurements. Statistical analyses were performed using Past-free software for scientific data analysis including univariate and multivariate statistics ${ }^{46}$.

Palaeotemperature calculations. Calcite temperatures were calculated using the equation of Anderson and Arthur ${ }^{47}$, modified by Coplen et al. ${ }^{48}$, assuming a $\delta^{18} \mathrm{O}$ value of $-1 \%$ for non-glacial sea water in accordance with palaeoposition and climate of Chełm site during the time-interval studied (compare Thibault et al $^{14}$, p. 436):

$$
\begin{aligned}
\mathrm{T}\left({ }^{\circ} \mathrm{C}\right)= & 16-4.14\left(\delta^{18} \mathrm{O}_{\mathrm{c}}-\left(1.03086\left(\left(\delta^{18} \mathrm{O}_{\mathrm{w}}-30.91\right) / 1.03091\right)+30.86\right)\right) \\
& +0.13\left(\delta^{18} \mathrm{O}_{\mathrm{c}}-\left(1.03086\left(\left(\delta^{18} \mathrm{O}_{\mathrm{w}}-30.91\right) / 1.03091\right)+30.86\right)\right)^{2}
\end{aligned}
$$

Sample processing in search of pyrite framboids. Samples of approximately $15 \mathrm{~g}$ of chalk from each of the three sampling intervals at Chełm (A-C) were studied in search of pyrite framboids. These samples were roughly grounded and then put in a solution of hydrochloric acid at a $\mathrm{pH}$ of 5.0 so as to dissolve the carbonate fraction. The insoluble residue was neutralized by washing it with demineralized water and ethanol. The samples were left drying for 2 days at room temperature and then roughly grounded again. The powder was placed on stubs, sputter coated with platinum and examined in a Philips XL-20 SEM (IP PAS).

Sample processing for REE analyses. Three chalk samples from intervals A-C of the Chelm succession and a comparative sample of the upper upper Maastrichtian spiculitic limestone of opoka type from a quarry at Wola Piasecka, southeast Lublin, were studied for Rare Earth Elements (REE) content. Samples were powdered and analyzed at the Bureau Veritas Acme Labs Canada Ltd. The contents of major, minor and rare elements were analyzed using inductively coupled plasma mass spectrometry (ICP-MS) methods. The precision and accuracy of the results were better than $\pm 0.05 \%$ (mostly $\pm 0.01 \%$ ) for the major elements and commonly better than $\pm 1 \mathrm{ppm}$ for the trace elements. The concentrations of REE were normalized to Post-Archean Australian Shales (PAAS) ${ }^{49}$ as indicated by the subscript ' $N$ '. Enrichment of HREEs was calculated as $\mathrm{Yb}_{\mathrm{N}} / \mathrm{Nd}_{\mathrm{N}}$ owing to the presence of positive La anomalies and highly variable, negative Ce anomalies in shallow seawater. $\mathrm{Ce}_{\mathrm{N}}$ anomalies were calculated following the relationship presented by Webb and $\mathrm{Kamber}^{50}$ :

$$
\mathrm{Ce}_{\mathrm{N}} / \mathrm{Ce}_{\mathrm{N}}^{*}=\mathrm{Ce}_{\mathrm{N}} /\left(0.5 \times \mathrm{La}_{\mathrm{N}}+0.5 \times \mathrm{Pr}_{\mathrm{N}}\right)
$$

Figure processing. All figures in this paper, including those in Supplementary Material, were prepared using CorelDraw 18 (https://www.corel.com/pl/?link=wm) and Adobe Photoshop CS3 (https://www.adobe. $\mathrm{com} / \mathrm{de} /$ creativecloud/desktop-app.html?mv=affiliate\&mv2=red).

Received: 24 July 2021; Accepted: 11 November 2021

Published online: 23 November 2021 


\section{References}

1. Landman, N. H. et al. (eds) Ammonoid Paleobiology (Plenum, 1996). https://doi.org/10.1007/978-1-4757-9153-2_16.

2. Klug, C. et al. (eds) Ammonoid Paleobiology: From Anatomy to Ecology (Springer, 2015). https://doi.org/10.1007/978-94-017-96309

3. Klug, C. et al. (eds) Ammonoid Paleobiology: From Macroevolution to Paleogeography (Springer, 2015). https://doi.org/10.1007/ 978-94-017-9633-0.

4. Ritterbush, K. A., Hoffmann, R., Lukeneder, A. \& De Baets, K. Pelagic palaeoecology: The importance of recent constraints on ammonoid palaeobiology and life history. J. Zool. 292(4), 229-241. https://doi.org/10.1111/jzo.12118 (2014).

5. Westermann, G. E. G. Ammonoid life and habitat. In Ammonoid Paleobiology (eds Landman, N. H. et al.) 607-707 (Plenum, 1996). https://doi.org/10.1007/978-1-4757-9153-2_16.

6. Lukeneder, A. Ammonoid habitats and life history. In Ammonoid Paleobiology: From Anatomy to Ecology (eds Klug, C. et al.) 689-791 (Springer, 2015). https://doi.org/10.1007/978-94-017-9630-9_18.

7. Hoffmann, R. et al. A novel multiproxy approach to reconstruct the paleoecology of extinct cephalopods. Gondwana Res. 67, 64-81. https://doi.org/10.1016/j.gr.2018.10.011 (2018).

8. Hoffmann, R. et al. Recent advances in heteromorph ammonoid palaeobiology. Biol. Rev. Cambr. Philos. Soc. 96, 576-610. https:// doi.org/10.1111/brv.12669 (2021).

9. Moriya, K., Nishi, H., Kawahata, H., Tanabe, K. \& Takayanagi, Y. Demersal habitat of Late Cretaceous ammonoids: Evidence from oxygen isotopes for the Campanian (Late Cretaceous) northwestern Pacific thermal structure. Geology 31, 167-170 (2003).

10. Moriya, K. Isotope signature of ammonoid shells. In Ammonoid Paleobiology: From Anatomy to Ecology (eds Klug, C. et al.) $793-836$ (Springer, 2015). https://doi.org/10.1007/978-94-017-9630-9_19.

11. Sessa, J. A. et al. Ammonite habitat revealed via isotopic composition and comparisons with co-occurring benthic and planktonic organisms. PNAS 112, 15562-15567. https://doi.org/10.1073/pnas.1507554112 (2015).

12. Stevens, K., Mutterlose, J. \& Wiedenroth, K. Stable isotope data $\left(\delta^{18} \mathrm{O}, \delta^{13} \mathrm{C}\right)$ of the ammonite genus Simbirskites-Implications for habitat reconstructions of extinct cephalopods. Palaeogeogr. Palaeoclimatol. Palaeoecol. 417, 164-175. https://doi.org/10.1016/j. palaeo.2014.10.031 (2015).

13. Surlyk, F., Dons, T., Clausen, C. K. \& Higham, J. Upper Cretaceous. In The Millennium Atlas: Petroleum Geology of the Central and Northern North Sea (eds Copestake, P. et al.) 213-233 (Geological Society of London, 2003).

14. Thibault, N., Harlou, R., Schovsbo, N. H., Stemmerik, L. \& Surlyk, F. Late Cretaceous (late Campanian-Maastrichtian) sea surface temperature record of the Boreal Chalk Sea. Clim. Past 12, 429-438. https://doi.org/10.5194/cp-12-429-2016 (2016).

15. Wilmsen, M. \& Niebuhr, B. High-resolution Campanian-Maastrichtian carbon and oxygen stable isotopes of bulk-rock and skeletal component: Palaeoceanographic and palaeoenvironmental implications for the Boreal shelf sea. Acta Geol. Pol. 67, 47-74. https:// doi.org/10.1515/agp-2017-0004 (2017).

16. Birkelund, T. Ammonites from the Maastrichtian White Chalk of Denmark. Bull. Geol. Soc. Denmark 40, 33-81 (1993).

17. Niebuhr, B. Late Campanian and Early Maastrichtian ammonites from the white chalk of Kronsmoor (northern Germany)-Taxonomy and stratigraphy. Acta Geol. Pol. 53, 257-281 (2003).

18. Kruta, I. \& Landman, N. H. Injuries on Nautilus jaws: Implications for the function of ammonite aptychi. Veliger 50, 241-247 (2008).

19. Tanabe, K., Kruta, I. \& Landman, N. H. Ammonoid buccal mass and jaw apparatus. In Ammonoid Paleobiology: From Macroevolution to Paleogeography (eds Klug, C. et al.) 439-494 (Springer, 2015).

20. Kruta, I., Landman, N. H. \& Cochran, J. K. A new approach for the determination of ammonite and nautilid habitats. PLoS ONE 9, e87479. https://doi.org/10.1371/journal.pone.0087479 (2014).

21. Machalski, M. Late Maastrichtian and earliest Danian scaphitid ammonites from central Europe: Taxonomy, evolution, and extinction. Acta Palaeontol. Pol. 50(4), 653-696 (2005).

22. Machalski, M. Correlation of shell and aptychus growth provides insights into the palaeobiology of a scaphitid ammonite. Palaeontology 64, 225-247. https://doi.org/10.1111/pala.12519 (2021).

23. Dubicka, Z. \& Peryt, D. Integrated biostratigraphy of Upper Maastrichtian chalk at Chełm (SE Poland). Ann. Soc. Geol. Pol. 81, 185-197 (2011).

24. Dubicka, Z. \& Peryt, D. Latest Campanian and Maastrichtian palaeoenvironmental changes: Implications from an epicontinental sea (SE Poland and western Ukraine). Cret. Res. 37, 272-284. https://doi.org/10.1016/j.cretres.2012.04.009 (2012).

25. Machalski, M. \& Malchyk, O. Durophagous predation on late Maastrichtian (Cretaceous) scaphitid ammonites from Poland. In 10th International Symposium "Cephalopods-Present and Past", Program and Abstracts. Münstersche Forschungen zur Geologie und Paläontologie 110,77-78 (2018).

26. Keupp, H. Sublethal punctures in body chambers of Mesozoic ammonites (forma Aegra fenestra n. f.), a tool to interpret synecological relationships, particularly predator-prey interactions. Paläontol. Z. 80, 112-123. https://doi.org/10.1007/BF02988971 (2006).

27. Mironenko, A. Sublethal injuries on the shells of Jurassic ammonites from Central Russia. In Jurassic Deposits of the Southern Part of the Moscow Syneclise and Their Fauna (eds Rogov, M. A. \& Zakharov, V. A.) 183-208 (Transactions of the Geological Institute, GEOS, 2017) (in Russian).

28. Moriya, K. Evolution of habitat depth in the Jurassic-Cretaceous ammonoids. PNAS 112, 15540-15541. https://doi.org/10.1073/ pnas.1520961112 (2015).

29. Leszczyński, K. The internal geometry and lithofacies pattern of the Upper Cretaceous-Danian sequence in the Polish Lowlands. Geol. Q. 56, 363-386. https://doi.org/10.7306/gq.1028 (2012).

30. Jurkowska, A. \& Świerczewska-Gładysz, E. New model of Si balance in the Late Cretaceous epicontinental European Basin. Global Planet. Change 186, 103108. https://doi.org/10.1016/j.gloplacha.2019.103108 (2020).

31. Müller, R. D. et al. GPlates: Building a virtual Earth through deep time. Geochem. Geophys. Geosyst. 19, 2243-2261. https://doi. org/10.1029/2018GC007584 (2018).

32. Walaszczyk, I., Dubicka, Z., Olszewska-Nejbert, D. \& Remin, Z. Integrated biostratigraphy of the Santonian through Maastrichtian (Upper Cretaceous) of extra-Carpathian Poland. Acta Geol. Pol. 66, 321-358. https://doi.org/10.1515/agp-2016-0016 (2016).

33. Surlyk, F. et al. Upper Campanian-Maastrichtian holostratigraphy of the eastern Danish Basin. Cret. Res. 46, 232-256. https://doi. org/10.1016/j.cretres.2013.08.006 (2013).

34. Tagliavento, M., Lauridsen, B. W. \& Stemmerik, L. Episodic dysoxia during Late Cretaceous cyclic chalk-marl deposition-Evidence from framboidal pyrite distribution in the upper Maastrichtian Rørdal Mb., Danish Basin. Cret. Res. 106, 104223. https://doi.org/ 10.1016/j.cretres.2019.104223 (2020).

35. Dubicka, Z., Wierzbowski, H. \& Wierny, W. Oxygen and carbon isotope records of Upper Cretaceous foraminifera from Poland: Vital and microhabitat effects. Palaeogeogr. Palaeoclimatol. Palaeoecol. 500, 33-51. https://doi.org/10.1016/j.palaeo.2018.03.029 (2018).

36. Klompmaker, A. A., Waljaard, N. A. \& Fraaije, R. H. B. Ventral bite marks in Mesozoic ammonoids. Palaeogeogr. Palaeoclimatol. Palaeoecol. 280, 245-257. https://doi.org/10.1016/j.palaeo.2009.06.013 (2009).

37. Fraaye, R. H. B. Late Cretaceous swimming crabs: Radiation, migration, competition, and extinction. Acta Geol. Pol. 46, 269-278 (1996).

38. Caldwell, R. L. \& Dingle, H. Stomatopods. Sci. Am. 234, 80-89 (1976) 
39. Dunstan, A. J., Ward, P. D. \& Marshall, N. J. Vertical distribution and migration patterns of Nautilus pompilius. PLoS ONE 6, e16311. https://doi.org/10.1371/journal.pone.0016311 (2011).

40. Ward, P., Dooley, F. \& Barord, G. J. Nautilus: Biology, systematics, and paleobiology as viewed from 2015. Swiss J. Palaeontol. 135, 169-185. https://doi.org/10.1007/s13358-016-0112-7 (2016).

41. Landman, N. H., Cobban, W. A. \& Larson, N. L. Mode of life and habitat of scaphitid ammonites. Geobios 45, 87-98. https://doi. org/10.1016/j.geobios.2011.11.006 (2012).

42. Peterman, D. J. et al. Syn vivo hydrostatic and hydrodynamic properties of scaphitid ammonoids from the U.S. Western Interior. Geobios 60, 79-98. https://doi.org/10.1016/j.geobios.2020.04.004 (2021).

43. Tsujita, C. J. \& Westermann, G. Ammonoid habitats and habits in the Western Interior Seaway: A case study from the Upper Cretaceous Bearpaw Formation of southern Alberta, Canada. Palaeogeogr. Palaeoclimatol. Palaeoecol. 144, 135-160. https://doi. org/10.1016/S0031-0182(98)00090-X (1998).

44. Fraaije, R. H. B., Van Bakel, B. W. M., Jagt, J. W. M. \& Viegas, P. A. The rise of a novel, plankton-based marine ecosystem during the Mesozoic: A bottom-up model to explain new higher-tier invertebrate morphotypes. Boletín de la Sociedad Geol. Mexicana 70, 187-200. https://doi.org/10.18268/bsgm2018v70n1a11 (2018).

45. Alldredge, A. L. \& King, J. M. The distance demersal zooplankton migrate above the benthos: Implications for predation. Marine Biol. 84, 253-260. https://doi.org/10.1007/BF00392494 (1985).

46. Hammer, O., Harper, D. A. T. \& Ryan, P. D. PAST: Paleontological statistics software package for education and data analysis. Pal. Electron. 4, 1-9 (2001)

47. Anderson, T. F. \& Arthur, M. A. Stable isotopes of oxygen and carbon and their application to sedimentologic and paleonvironmental problems. In Stable Isotopes in Sedimentary Geology, The Society of Economic Paleontologists and Mineralogists Short Course Vol. 10 (eds Arthur, M. A. et al.) 1-151 (SEPM, 1983). https://doi.org/10.2110/scn.83.01.0000.

48. Coplen, T. B., Kendall, C. \& Hopple, J. Comparison of stable isotope reference samples. Nature 302, 236-238. https://doi.org/10. 1038/302236a0 (1983)

49. McLennan, S. M. Rare earth elements in sedimentary rocks: Influence of provenance and sedimentary process. Rev. Mineral. 21, 169-200 (1989).

50. Webb, G. E. \& Kamber, B. S. Rare earth elements in Holocene reefal microbialites: a new shallow seawater proxy. Geochim. Cosmochim. Acta 64, 1557-1565. https://doi.org/10.1016/S0016-7037(99)00400-7 (2000).

\section{Acknowledgements}

This work was financed by the National Science Centre, Poland, grant 2015/19/B/ST10/02033 to M.M. Cathodoluminescence imaging was performed in the NanoFun laboratory (Laboratory of Cathodoluminescence, Institute of Paleobiology PAS, Warsaw) co-financed by the European Regional Development Fund within the Innovation Economy Operational Programme POIG.02.02.00-00-025/09. We thank M. Andziak for field assistance, C. Kulicki for SEM assistance, G. Dziewińska and M. Dziewiński for photographic work, A. Hołda-Michalska for computer-processing of figures (all from Institute of Paleobiology PAS), B. Waksmundzki (University of Warsaw) for drawings of ammonoid specimens, B. Gebus-Czupyt (Warsaw Isotope Laboratory for Dating and Environment Studies of the Polish Academy of Sciences) for isotope analyses, J.W.M. Jagt (Natural History Museum Maastricht, the Netherlands) for linguistic help, N. Thibault (University of Copenhagen, Denmark) for providing samples from Stevns 1 core, and M. Yacobucci (Bowling Green State University, the USA) for assistance with estimation of the palaeocoordinates of Chełm site. The staff of the Cemex Polska is thanked for assistance in various ways.

\section{Author contributions}

M.M., K.O. and Z.D. designed research. M.M and O.M. collected the macrofossil material and are responsible for field observations. K.O. is responsible for processing of geochemical and other analytical data, and for statistical tests. Z.D. and W.W. are responsible for foraminiferal data. O.M. participated in analysis of predation marks. M.M. is responsible for all ammonoid-related data and wrote the main text and the text of Supplementary Information, in cooperation with Z.D. and K.O. All authors discussed the results and reviewed the manuscript.

\section{Competing interests}

The authors declare no competing interests.

\section{Additional information}

Supplementary Information The online version contains supplementary material available at https://doi.org/ 10.1038/s41598-021-02236-9.

Correspondence and requests for materials should be addressed to M.M.

Reprints and permissions information is available at www.nature.com/reprints.

Publisher's note Springer Nature remains neutral with regard to jurisdictional claims in published maps and institutional affiliations.

Open Access This article is licensed under a Creative Commons Attribution 4.0 International format, as long as you give appropriate credit to the original author(s) and the source, provide a link to the Creative Commons licence, and indicate if changes were made. The images or other third party material in this article are included in the article's Creative Commons licence, unless indicated otherwise in a credit line to the material. If material is not included in the article's Creative Commons licence and your intended use is not permitted by statutory regulation or exceeds the permitted use, you will need to obtain permission directly from the copyright holder. To view a copy of this licence, visit http://creativecommons.org/licenses/by/4.0/.

(c) The Author(s) 2021 